\title{
Education of foreign children - integration or disintegration of identity
}

\section{Introduction}

Recently provided information shows that "in the 2018/2019 school year 44 thousand of foreign children studied in Polish schools. [...] data for the current school year will be available at the turn of October and November. For the first time, it includes information about pupils' nationality" (Rośnie..., 2019). The number of Ukrainians as at October 8, 2019 officially recorded in the register of the Lubuskie Region amounts to 8,799 (out of the total number of 16,443 registered persons). The remaining include: 4,565 from Germany, 455 - Bulgaria, 366 - Belarus, 2,258 - other nationality (Statystyki, 2019). Analyzing different available sources, it is very difficult to assess the whole scale of the phenomenon properly. Available data, especially concerning temporary migrations, is unfortunately very limited (Ośrodek Studiów Wschodnich, 2017: 2).

However, basing on available information, it can be clearly seen that year by year the number of immigrants in Poland is increasing. This requires various changes and attempts to adjust the environment to new situations. One of them involves the appearance of children along with incoming immigrants, who in accordance with the Polish law must attend school and participate in compulsory education. It is not a marginal question as evidenced by the fact that

in recent years the number of foreign children in Polish schools has been increasing significantly. In the previous school year, there were 44 thousand children studying in more than 7 thousand school, the year before that - 30 thousand children in close to 6 thousand schools, and in the 2015/2016 school year - 14 thousand children in more than 3 thousand schools. According to 2018 data, the most foreigners studied in schools in the following regions: Masovian, Lower Silesia and Lesser Poland (Rośnie..., 2019).

This data points to the necessity of managing the issue of education of foreign children, including also a discussion of a question of nurturing their identity.

\footnotetext{
* Correspondence address: Wydział Administracji i Bezpieczeństwa Narodowego, Akademia im. Jana z Paradyża w Gorzowie Wielkopolskim, ul. Fryderyka Chopina 52, budynek 7, 66-400 Gorzów Wielkopolski, Polska, e-mail: baorlowska@op.pl.
} 
The purpose of this paper is to attempt to show certain difficulties faced by the family, the school and the child itself as a result of often such sudden and significant changes. Singling out the number of foreign children out of available data, including Ukrainian children residing with their parents on the territory of Poland, is nevertheless, difficult. Unfortunately, the Educational Information System gathers little data in this regard and there is lack of detailed information. As assured by the Ministry of National Education, "with the beginning of oncoming school year information about pupils' nationalities will also be collected" (Rośnie..., 2019). The paper also aims to demonstrate various related difficulties and problems faced by the family, the school and also the children themselves and the teachers. An analysis of available data and literature allowed a certain look at and reflection on the question of possibilities and directions of support for foreign children, including Ukrainian children who are present in Polish schools in such great number.

\section{Migrations - their contemporary contexts}

The migration context has its reference to various issues that contemporary nations need to face. Migration is most often understood as a "permanent change of the country of residence the aim of which is to change the migrant's main place of residence" (Ośrodek Studiów Wschodnich, 2017: 2). A question arises, however, what permanent change of the country of residence means. Additionally, it is worth looking at migration through the prism of migration streams. Migration streams are nothing else but "the number of migrants leaving a country (emigration stream) or arriving in a country (immigration stream) during a certain period of time (e.g. in a year)" (Ośrodek Studiów Wschodnich, 2017: 2). This issue involves the question of migration resources understood as the number of "migrants in a given country at a given point in time. For statistical purposes December 31 of a given year is usually taken into consideration" (Ośrodek Studiów Wschodnich, 2017: 3).

This perspective makes it possible to assess the phenomenon and shows a certain trend of incidence of migration. It is also essential that certain information can be obtained i.a. from the Office for Foreigners. However, this office

only gathers data about children who are in the course of a refugee procedure. At the moment, it is approximately 850 school-age children (in previous years these numbers hovered between 1,200 in 2016 and 900 in 2018). They attend public schools on the same terms as Polish children. Majority of them are currently staying in 10 refugee centres seeking international protection. Most of them stay in the Łuków, CzerwonyBór and Linin locations. Citizens of Russia (mostly of Chechen nationality), Ukraine and Tajikistan prevail among them (Rośnie..., 2019).

On the basis of the current EU laws (European Union: European Parliament, 2017), it can be noted that the movement of people on the Ukraine-Poland line has gained great vitality. A very intensive increase of migration from this direction after 2014 can 
also be observed. As the research shows, these are not only work-related movements. A very intensive increase of youth migration has also occurred. As emphasized by the research authors, it revealed that

among current migration trends and behaviours new, or previously not so common, trends have occurred such as: youth and student migration (as a result of active enrolment campaigns carried out by Polish universities), young specialists, small and medium entrepreneurs and family reunification (Ośrodek Studiów Wschodnich, 2017: 11).

It is the latter migration behaviour that became this paper's focus. Family reunification results in children also arriving in the country of settlement. They must adjust to the new reality of the country of arrival as well as the school or a new place of settlement.

\section{Nurturing identity - maintaining it and passing it on}

In view of the above, an issue of the context of identity appears. Each nationality has its characteristic identity. This makes it possible to differentiate between representatives of one nationality and another. Therefore, a question arises whether identity of every man should remain unchanged, without interference with its individual elements. Having a lot of determinants, including language, religion or culture, it results in us dealing with multiplicity and diversity around. Everything is unnoticeable when one is part of the majority. The situation looks different when the identity of representatives of a minority who stand out against the majority is examined. Their different language, culture and often also religion make us become more distrustful and distanced.

The simplest definition of identity involves an attempt to answer the question of who I am. Exploring this issue for instance on the basis of the theories of Zbigniew Bokszański (Bokszański, 2006: 13-43) or George H. Mead (Mead, 1975: 240-247) unfortunately does not demist the outlook on the issue of identity, but quite the contrary, it makes it even more complex and complicated. "The place of identity in a dynamic social structure is associated with space referred to as homeland by Stanisław Ossowski. Homeland or family are not geographical notions as they refer to psychological attitudes of the entire population" (Łyszczarz, 2013: 38).

This variety of views on the definition of identity makes the situation even more complicated in the case of a minority group. According to Michał Łyszczarz,

in ethnicity studies this notion gains cultural meaning. Identity understood in this way, based on values and ideas (e.g. patriotism), is a result of creating a specific image of oneself which emphasizes the awareness of otherness and the place in one's own group. [...]. The existence and role of identity become apparent especially in a situation of a threat, manifested in internal conflicts as well as through contact with a foreign culture pursuing domination (an example here comes in the concept of Samuel Huntington's so-called clash of civilizations [Huntington 2003: 307-428] (Łyszczarz, 2013: 37). 
When talking about foreign children's presence in Poland, it is worth referring to the issue of ethnic identity as a specific type of identity. Eyszczarz points out that it is "a broad concept of a collective and comprehensive character" (Łyszczarz, 2013: 41). As Ewa Nowicka emphasizes in her reflections, ethnic identity is made up of a number of different elements. As most significant the author lists the language, religion, customs and economic behaviour. But not only that. She points out that elements such as a conviction of a common origin or biological bloodline are equally important. One cannot leave out the relationship with a territory (the so-called territorial ethnicity) or similarity of human physical or racial features, either. This all makes the notion of identity a complex area of contemporary research and analysis (Nowicka, 2006: 382-384). Whereas Anthony D. Smith classified and singled out certain ethnicity-related features which make up the characteristic ethnic identity of a given group (Smith, 2009: 31-43). This makes it possible to examine individual groups better and to specify the ethnic processes occurring within them.

In view of the above, in the face of a new situation, how must we nurture the identity of children arriving in the country of settlement? What to do so that these children do not lose their own identity and at the same time are able to cope in a new situation of the identity of the foreign country's majority, with a foreign language, not always understood by the children? Both the family and the school play a great role here. These two environments in which the child is functioning should make sure that the child steps into the new environment in the place of settlement appropriately, giving them at the same time a chance not to lose the identity of their predecessors' country of origin.

At the start, it is worth addressing the issue of what foreign and minority children we may be dealing with now. As pointed out by the authors of the report An alien in a Polish school, we may be dealing with different groups of foreigners and representatives of minorities. The most important of them include: " $1 /$ Children of refugees and of persons seeking refugee status. 2/ Children of immigrants with various statuses (seasonal workers, persons with a tolerated stay permit, persons under temporary protection, illegal immigrants, others). 3/ Children of workers migrating from the European Union states. 4/ Foreign students. 5/ National minority children, especially the Romani. 6/Children of repatriates. 7/ Children from mixed marriages" (Bernacka-Langier, 2010: 9).The diversity of these groups results in a diversity of needs and expectations in the context of i.a. education.

Education also entails various problems which result from i.a. forced migration. They include, among others: the lack of access to school for children or superficial access to school and education, language barrier, educational gap, sense of temporariness, learnt helplessness, conflicts, post-traumatic stress disorder, mourning one's culture, survivor guilt, abandoning unfinished matters (Piegat-Kaczmarczyk, Rejmer, 2010: 22-24). As a consequence, it is observed that 
children of migrants and refugees experience entering a new school environment hard. They fear contact with classmates and teachers. This situation may negatively affect their functioning in a school. This is why the teacher's role is extremely important, who should prepare his pupils and their parents for the admittance of a foreign child and provide support for the child and his family in understanding unclear (for foreigners) norms of our culture (Piegat-Kaczmarczyk, Rejmer, 2010: 25).

After arriving in the country of new settlement, the migrant's passing through the stages of the culture shock is observed. Entering a new group, often close-knit and speaking in a different language on top of that, a pupil may experience the said culture shock. What is more, he or she enters a new school and meets with new teachers' requirements and a different system of studying or working, etc. Such pressure of otherness may overwhelm children and make them withdrawn, introverted and unapproachable. And here comes in the teacher's role, who should support pupils in an appropriate way and aid them in going through the individual phases of the culture shock including: the honeymoon, first phase of shock, second phase of shock, understanding, intercultural competence (Piegat-Kaczmarczyk, Rejmer, 2010: 25-27). A question arises of how to help the student to wade through all these phases. First, it is worth remembering that migrant pupils often arrived in the country of settlement as they were forced to do so and often without prior preparation. This means, in consequence, that the first stage, i.e. the honeymoon, does not happen for them. In further stages "reality turns out to be more surprising and otherness is definitely in their way and irritates more than it brings joy. Daily cultural errors and misunderstandings cause strong frustration and anger at oneself. This results in withdrawal from school life and reluctance to socialize" (Piegat-Kaczmarczyk, Rejmer, 2010: 26). This, in turn, may lead to even greater misunderstandings. It is a consequence of functioning in a culturally different environment.

Strong physical and psychological exhaustion may result in weakness and proneness to falling ill. The direction of anger and aggressionshifts from oneself to 'them'. A conviction dominates that 'they', that is members of the host society, are evil, behave inappropriately and are reluctant towards me. Fits of anger or aggression against pupils of the majority group may occur (PiegatKaczmarczyk, Rejmer, 2010: 26).

Looking from the perspective of interculturality, it might be worth using cultural aspects for greater integration of foreign children in Polish schools. Why is it so important? Geert Hofstede points out that culture means collective programming of the mind (Hofstede, 2000: 40). It means that "culture is a customary, traditional way of thinking and acting which new members of the culture must become acquainted with" (Piegat-Kaczmarczyk, Rejmer, 2010: 16). Using intercultural education for this purpose, we are giving a chance both to foreign children and representatives of the majority to learn one another. 


\section{Polish school in the face of a foreign child (Orłowska 2019)}

The Polish school has already got some experience working with foreign children. However, the changing dynamic reality shows that still both regulations as well as the work with the pupil itself need to be adjusted to the occurrinwg difficulties.

As the Ministry of Education informs, the basis for admitting a foreign child to a school in Poland involves documents issued by the school abroad in which the pupil had been receiving compulsory education. A foreign student has the right to at least two hours of Polish language instruction a week. They can also participate in additional compensatory classes in other subjects if the lead teacher sees such a need. The total number of additional Polish language instruction and compensatory classes must not exceed 5 hours a week - the Ministry informed (Rośnie..., 2019).

A foreign pupil appearing at school does not have an easy life. A new country, a new language, a new school, new friends, a new environment. This all makes it not effortless to adapt to new surroundings. On top of that, school requirements which are often different to previous ones. These changes may bring about different reactions in children. Analyzing the education process, one needs to take into account the changes in the structure of the school class, which significantly transform the picture of a class uniform in terms of nationality into one that is linguistically and nationality-wise diverse. Teachers should prepare their students for an arrival of a child from a different culture or country. Parents, too, should be aware of the presence of 'new' children in their children's class. This is to aid students' better preparation for welcoming a new classmate. Why?

In daily work with foreign students, a lot may surprise. The teacher may not be able to understand the children's behaviours. On the other hand, teacher's instructions and behaviours may be wrongly interpreted by children of a different nationality. This occurs because the culture we live in determines our perception of the world. [...] Understanding cultural differences is the first step to coping effectively and to preventing potential misunderstandings in an intercultural school (Piegat-Kaczmarczyk, Rejmer, 2010: 15).

The effects of forced migrations, which leave a powerful mark on both the child and their parents, should be considered with emphasis. They can be classified into a number of fundamental groups which profoundly affect the functioning of the child i.a. at school. Most of all

the lack of access to schools for children or apparent access to school and education disturbs the children's cognitive and intellectual development and distorts their socialisation process. School education plays an important role in the life of a little refugee in restoring stabilization, peer group belonging and intellectual, emotional and social development (Piegat-Kaczmarczyk, Rejmer, 2010: 22).

The second problem worth noting is the language barrier accompanying the change of a country of residence that makes children, young people and adults feel insecure in contact with the hosts. This insecurity often transforms into fear, which leads to withdrawal from contact or to aggression. [...] For children attending school the lack of knowl- 
edge of the Polish language or its insufficient knowledge becomes a barrier in establishing contacts, solving misunderstandings, further education and extending knowledge in other subjects (Piegat-Kaczmarczyk, Rejmer, 2010: 22).

Pointing to other difficulties, one cannot omit the likelihood of an educational gap or the sense of temporariness, which is often the reason for reluctance towards studying and school "as not bringing any noticeable benefits in their view" (Piegat-Kaczmarczyk, Rejmer, 2010: 22).

Apart from these examples of difficulties, marital and intergenerational conflicts are also observed. It is "the family that usually provides a strong support system which helps survive the most difficult period of adaptation to a new culture. At the same time, anintergenerational conflict often occurs under the new circumstances, which is rather likely to intensify in a new cultural environment. Children usually grow into the new culture faster than adults" (Piegat-Kaczmarczyk, Rejmer, 2010: 22). The post-traumatic stress disorder, the survivor guilt, leaving behind unfinished matters or mourning one's culture may add to that, which affects a lot of migrants, including children. It is suffering triggered as a result of leaving the country as well as the loss of people or things which were important to an individual.

The loss of a socio-cultural environment of homeland is for many migrants a source of strong and very difficult emotions. Many of them, despite physical functioning in a new place still live the affairs of their homeland and identify themselves more with the past than with the future. Mourning one's culture enhances reluctance to take any binding decisions in the host country, such as taking up permanent employment or investing in the children's education (Piegat-Kaczmarczyk, Rejmer, 2010: 23).

Entering into a new culture may cause a culture shock, especially in children. Hence the need to shape intercultural competences in a student. Thanks to the experience and the course of the process of students' learning, "an ability to function healthily and efficiently in both cultural contexts is created. The sense of stability and security returns. A pupil feels comfortable both in his own culture as well as the new one - he is aware of the cultural similarities and differences" (Piegat-Kaczmarczyk, Rejmer, 2010: 27).

\section{Integration or disintegration}

Analyzing the existing data found in the literature, it is worth emphasizing that school is an important place that shapes different competences. Of course, a question arises whether the foreign children's acquisition of the competences which are necessary for the correct course of the integration process in a new country, at the same time, will not bring about disintegration of the identity of the country of origin. As representative of the majority we often forget that the "process of entering into a circle of a different reality (acculturation) is long and entails continuous gathering of new, often difficult expe- 
riences on all planes of human activity" (Młynarczuk-Sokołowska, 2015: 19). As a consequence, it may lead to a situation in which

acculturation may take many forms and lead to different results, thus entailing changes in the system of values, a catalogue of behaviours as well as identity. The discussed process may result in integration, assimilation, separation or marginalization. From the point of view of mental health and chances for full functioning in a new country, the optimal strategy involves integration which is a result of meeting and dialogue between the culture of the country of the new-comers and the culture of the host country (Młynarczuk-Sokołowska, 2015: 20).

These activities significantly contribute to the children's better adaptation in a school class. However, it needs to be remembered not to force certain changes, which sometimes we as teachers expect to come much quicker. Each child needs time to get familiar with the new situation and the teacher should serve as the pupil's support and guide on this path and not a 'herdsman' who will bring about a result different to the one expected. As pointed out by Sheili Melzak, a young person needs comprehensive support which will him or her them to adapt to a new situation. One of these support areas includes shaping the student's

sense of internal stability and strength. This is served by five types of activities focuses on different aspects of a man's functioning: 1 / sense of belonging - to a family, but also a school, class; 2 / allowing reflection, reminiscing past difficult experiences [...];3/ active problem solving [...]; 4/ creativity - art has a therapeutic role. [...]; 5/ sense of being part of a community (Kosowicz, 2010:38).

\section{Conclusions}

The dynamics of changes currently observed dictate that we all should be aware of the weight of the problem faced by schools and teachers now. Multiplicity and diversity at school in a way force teachers to acquire multicultural competences which will make their work with a multicultural class easier. However, a question arises here: are teachers prepared for this? The lack of detailed data results in the fact that it is difficult to prepare an adequate support offer for individual schools and groups. Without studying in depth the magnitude of this phenomenon and the assessment of possibilities of help, all actions are only apparent.

\section{Bibliography}

Biernacka-Langier A. (2010), Diagnoza sytuacji uczniów cudzoziemskich w warszawskich szkołach, [in:] Inny w polskiej szkole. Poradnik dla nauczycieli pracujących z uczniami cudzoziemskimi, edit. E. Pawlic-Rafalska, Warszawa, pp. 9-14.

Bokszański Z. (2006), Tożsamości zbiorowe, Warszawa.

Hofstede G. (2000), Kultura i organizacja. Zaprogramowanie umystu, Warszawa. Huntington S.P. (2003), Zderzenie cywilizacji i nowy kształt ładu światowego, Warszawa. Kosowicz A. (2010), Kilka słów od psychologa klinicznego, czyli dzieci wygrały bitwę, ale wciąż 
sa na wojnie, [in:] Inny w polskiej szkole. Poradnik dla nauczycieli pracujących $z$ uczniami cudzoziemskimi, edit. E. Pawlic-Rafalska, Warszawa, pp. 38-39.

Łyszczarz M. (2013), Młode pokolenie polskich Tatarów. Studium przemian generacyjnych młodzieży w kontekście religijności muzułmańskiej oraz tożsamości etnicznej, Olsztyn-Białystok.

Mead G.H. (1975), Umyst, osobowość i społeczeństwo, Warszawa.

Młynarczuk-Sokołowska A. (2015), Różnorodność w szkole. Ku integracji uczniów - uchodźców, “Trendy”, No. 4, pp. 18-23, http://www.bc.ore.edu.pl/Content/816/T4_15+Ku+integracji+uczniow-uchodzcow.pdf [access on: 3.11.2019].

Nowicka E. (2006), Świat człowieka - świat kultury. Wydanie nowe, Warszawa.

Orłowska B.A. (2019), Wsparcie edukacji dzieci cudzoziemskich - prawa, problemy, pomoc [in print].

Ośrodek Studiów Wschodnich (2017), Zniesienie obowiązku wizowego wobec obywateli Ukrainy - konsekwencje migracyjne dla Unii Europejskiej. Ekspertyza Ośrodka Studiów Wschodnich, https://udsc.gov.pl/wp-content/uploads/2017/11/Ekspertyza-OSW-\%E2\%80\%9EZniesienieobowi\%C4\%85zku-wizowego-wobec-obywateli-Ukrainy-\%E2\%80\%93-konsekwencjemigracyjne-dla-Unii-Europejskiej\%E2\%80\%9D.pdf [access on: 3.11.2019].

Piegat-Kaczmarczyk M., Rejmer Z. (2010), Psychologiczne skutki uchodźctwa, [in:] Inny w polskiej szkole. Poradnik dla nauczycieli pracujacych z uczniami cudzoziemskimi, edit. E. Pawlic-Rafalska, Warszawa, pp. 15-37.

European Union: European Parliament (2017), Resolution of the European Parliament of 6 April 2017, approved by the European Council on 26 April 2017, on adding Ukraine to the list of countries whose citizens do not need visas for short-term stays (up to 90 days within 180 days) within the Schengen zone.

Rośnie liczba dzieci cudzoziemskich w szkołach. Od tego roku dane nt. narodowości (2019), https:// edukacja.dziennik.pl/aktualnosci/artykuly/608377,dzieci-cudzoziemcy-szkoly-edukacjanarodowosci-nauczyciel.html [access on: 23.09.2019].

Smith A.D. (2009), Etniczne źródła narodów, Kraków.

Statystyki (2019), https://migracje.gov.pl/statystyki/zakres/polska/typ/dokumenty/widok/mapa/ rok $/ 2019 / ? \mathrm{x}=0.5603 \& \mathrm{y}=1.3184 \&$ level $=1.4768$ [access on: 8.10 .2019 ]

Abstract: The paper points to new difficulties and new expectations towards the Polish school. The presence of a greater number of immigrant students results in the school and teachers having to face new challenges. However, one often forgets that pupils too are put in a new school and in a new cultural situation. On top of that, pupils in a class that welcome new classmates should be prepared for the meeting with a different culture or tradition in order to understand their new friends better. One also needs to think how to support the child's parents for whom it is also a very difficult time. Support from the school, teachers and other parents is very important. It will enable the child to step into new duties more quickly and it will allow the parents to understand requirements and expectations.

Keywords: foreign student, identity, migration, school, education 